\title{
Molecular cloning and expression analysis of dmrt1 and sox9 during gonad development and male reproductive cycle in the lambari fish, Astyanax altiparanae
}

\author{
Mateus C Adolfi ${ }^{1,2^{*}}$, Ana CO Carreira ${ }^{3}$, Lázaro WO Jesus ${ }^{1}$, Jan Bogerd ${ }^{4}$, Rejane M Funes ${ }^{1}$, Manfred Schartl ${ }^{2}$, \\ Mari C Sogayar ${ }^{3}$ and Maria I Borella ${ }^{1}$
}

\begin{abstract}
Background: The dmrt1 and sox9 genes have a well conserved function related to testis formation in vertebrates, and the group of fish presents a great diversity of species and reproductive mechanisms. The lambari fish (Astyanax altiparanae) is an important Neotropical species, where studies on molecular level of sex determination and gonad maturation are scarce.

Methods: Here, we employed molecular cloning techniques to analyze the cDNA sequences of the dmrt1 and sox9 genes, and describe the expression pattern of those genes during development and the male reproductive cycle by qRT-PCR, and related to histology of the gonad.

Results: Phylogenetic analyses of predicted amino acid sequences of dmrt1 and sox 9 clustered A. altiparanae in the Ostariophysi group, which is consistent with the morphological phylogeny of this species. Studies of the gonad development revealed that ovary formation occurred at 58 days after hatching (dah), 2 weeks earlier than testis formation. Expression studies of sox9 and dmrt1 in different tissues of adult males and females and during development revealed specific expression in the testis, indicating that both genes also have a male-specific role in the adult. During the period of gonad sex differentiation, dmrt1 seems to have a more significant role than sox9. During the male reproductive cycle $d m r t 1$ and sox9 are down-regulated after spermiation, indicating a role of these genes in spermatogenesis.

Conclusions: For the first time the $d m r t 1$ and sox 9 were cloned in a Characiformes species. We show that both genes have a conserved structure and expression, evidencing their role in sex determination, sex differentiation and the male reproductive cycle in A. altiparanae. These findings contribute to a better understanding of the molecular mechanisms of sex determination and differentiation in fish.
\end{abstract}

Keywords: Teleostei, Sex differentiation, DMRT1, SOX9, Spermatogenesis

\footnotetext{
*Correspondence: mateus.adolfi@biozentrum.uni-wuerzburg.de

'Department of Cell and Developmental Biology, Institute of Biomedical

Science, University de São Paulo, São Paulo, SP, Brazil

${ }^{2}$ Department of Physiological Chemistry I, University of Würzburg, Am

Hubland, Würzburg, Germany

Full list of author information is available at the end of the article
}

\section{Biomed Central}

(c) 2015 Adolfi et al.; licensee BioMed Central. This is an Open Access article distributed under the terms of the Creative Commons Attribution License (http://creativecommons.org/licenses/by/4.0), which permits unrestricted use, distribution, and reproduction in any medium, provided the original work is properly credited. The Creative Commons Public Domain Dedication waiver (http://creativecommons.org/publicdomain/zero/1.0/) applies to the data made available in this article, unless otherwise stated. 


\section{Background}

The genetic machinery controlling gonad development is widely conserved, where downstream components tend to converge upon the regulation of common effectors. However, comparisons of the sex determination cascades in different organisms show an impressive diversity of 'master sex-determining genes' at the top of the genetic hierarchies [1]. In most mammals, it is well known that this process involves the action of a $\mathrm{Y}$ chromosomal master gene, named Sry [2]. In this case, once the sex is determined, it follows a unique path of development, producing testis or ovary [3,4]. In contrast, there are many exceptions to this rule in other vertebrates. In fish, gonad development can be influenced by fluctuations of intrinsic factors such as growth and behavior, and by extrinsic factors such as temperature, hormones and exposures to pollutants [5-12]. The medaka fish, like in mammals, possesses an XX-XY sex determination system in which the male is heterogametic, although, like others species of fish, the sex chromosome cannot be morphologically recognized [13]. A gene named $d m y$ or $d m r t 1 b Y$, that codes for a protein with the DM domain, was found in the sex determination region of the $Y$ chromosome of medaka. It is a duplicated version of the dmrt1a gene $[14,15]$. A study in medaka analyzed the main downstream sex determination genes, and showed major differences between mammals and medaka, notably amongst spatial and temporal expression patterns of the canonical signaling pathways, calling into question a strict conservation of regulatory and functional interactions of sexual development genes in vertebrates [16].

The dmrt1 gene (doublesex/mab-3 related transcription factor-1) belongs to the gene family first found in insects (doublesex) and nematodes (mab-3), both of which code for a DNA-binding protein with a zincfinger-like motif, named DM domain [17-19]. The dmrt1 gene seems to be the only gene whose structure and role are conserved during differentiation and gonad development in males, and which has been found throughout vertebrate evolution [19-26]. It is expressed in germ and Sertoli cells of mice testis, downstream from Sry [27]. Mutant $\mathrm{Dmrt1}^{-/-}$mice present severe testis problems, showing abnormalities and loss of Sertoli cells function, which may possibly explain the loss of germ cell numbers in these animals. Thus, Dmrt1 is necessary for survival and differentiation of germ and somatic cells in mammals [27].

Some species of turtles and all crocodiles do not have a sex chromosome, with sex being determined by the temperature at which the eggs are incubated [28]. Kettlewell et al. [29] showed that expression of dmrt1 in the genital ridge of turtle embryos was higher in those incubated at lower temperatures, which promotes the formation of male sex. Birds display the ZZ-ZW sex determination system, in which the female is heterogametic (ZW), and the best candidate for male sex determination is Dmrt1, located on the $\mathrm{Z}$ chromosome. This gene is expressed in bird embryos of both sexes, but at higher levels in (ZZ) males. Increased expression of this gene at the critical period of sex differentiation leads to testis development, showing a dosedependent expression for male formation [30,31].

In fish, all modalities of sex determination have been found, with or without specific sex chromosomes [32]. The dmrt1 gene was found to be expressed exclusively during the early stages of testis differentiation, but not in the ovary $[21,22,33]$. Induction of sex reversal with androgen in XX Nile tilapia increases the expression of $d m r t 1$ in the germ-cell-surrounding cells [6]. In Silurus meridionalis, two isoforms of dmrt1 were isolated (dmrt1a and $d m r 1 b$ ), with $d m r t 1 a$ being expressed exclusively in gonads, but at higher levels in testis, when compared with ovary. The same pattern was observed for $d m r t 1 b$, but, besides the gonads, this isoform was also expressed in other tissues, such as kidney and intestine [24].

It is well known that members of the SRY-box (Sox)family show a role in the formation of gonads. This family encodes a transcription factor which displays a DNAbind-motif, named SRY-like HMG (high mobility group). Sox9 is a member of Sox-family that plays an essential role in testis determination besides other functions, e.g. in cartilage formation [34,35]. This gene seems to be the main effector gene of Sry [36]. Sox9 mutations in an XY organism may lead to bone formation problems, gonad digenesis and sex reversal $[35,37,38]$. The sox 9 gene is conserved in mammals and birds, as well as preserved its structure and function in teleost fish [39-41]. In zebrafish, there are two copies of this gene $-\operatorname{sox} 9 a$ and sox $9 b$ - with $\operatorname{sox} 9 a$ expressed in testis and $\operatorname{sox} 9 b$ in adult ovary [42]. On the other hand, in medaka, sox $9 a$ is preferentially expressed in the brain and ovary, and $s o x 9 b$ is more expressed in testis than in ovary [43].

Astyanax altiparanae, popularly known as lambari, is a neotropical species with ecological and economical importance [44,45]. A. altiparanae was described as a new species in 2000 [46], and little information is available about its reproductive biology and sex differentiation. Recently, we described the morphological alterations of the testis of this species based on the alterations of the germinal epithelium (GE) throughout the annual reproductive cycle [47], but the alterations on the molecular level are not reported. Here, we report the isolation of dmrt1 and sox 9 sequences and their gene expression patterns during gonad development and in different testes maturation phases in Astyanax altiparanae.

\section{Methods}

Animals

Astyanax altiparanae belongs to the Class Actinopterygii, order Characiformes and the family Characidae, which is 
comprised exclusively of fresh water species, being widely distributed throughout the Paraná River [48].

Larvae and adults of $A$. altiparanae were collected in the Aquaculture and Hydrobiology Station from CESP, located in Paraibuna city, São Paulo State, Brazil. Larvae were raised in our laboratory and collected at 5, 12, 19, 26 and 33 days after hatching (dah). From the 40 dah stage onwards, 3 pools of male and female juvenile gonads $(n=10)$ were collected each week. Males $(n=3)$, between 6 and 18 months old, were also collected during the different periods of the reproductive cycle. Adults and juveniles were anesthetized with $0,1 \%$ benzocaine and then sacrificed by decapitation. All animal experiments were approved by the Committee of Laboratory Animal Experimentation at University of São Paulo (57/2009).

\section{Light microscopy}

Larvae and juvenile gonads from fish at different phases of development were dissected and fixed in Bouin's solution for $24 \mathrm{~h}$ at room temperature, subsequently dehydrated, embedded in paraffin or historesin (Leica), and then serially sectioned at 3 to $5 \mu \mathrm{m}$ thickness. The sections were counterstained with hematoxylin \& eosin.

\section{Cloning of A. altiparanae dmrt1 and sox9 cDNAs}

Tissues of $A$. altiparanae were stored in RNA holder (BioAgency) until RNA extraction. Total RNA was extracted using RNAeasy Mini Kit (Qiagen). First strand cDNA was synthesized with $2 \mu \mathrm{g}$ total RNA from gonadal tissues in combination with oligo- $\mathrm{dT}_{18}$ primer (Fermentas), random primers (Invitrogen) and SuperScript III reverse transcriptase (Invitrogen). Primer sets added to the PCR mixture for the amplification of $A$. altiparanae dmrt1 and sox 9 cDNA fragments were designed based on the conserved nucleotide regions of dmrt1 and sox 9 sequences of several organisms. PCR was performed in a PTC-225 Peltier Thermal Cycler (MJ Research) using the following parameters: $94^{\circ} \mathrm{C}$ for $30 \mathrm{sec}$, followed by 35 cycles of $94^{\circ} \mathrm{C}$ for $10 \mathrm{sec}, 50-58^{\circ} \mathrm{C}$ for $30 \mathrm{sec}$, and $72^{\circ} \mathrm{C}$ for $1 \mathrm{~min}$. The PCR was finished by a further incubation at $72^{\circ} \mathrm{C}$ for $10 \mathrm{~min}$. PCR products were gel-extracted from 1 to $2 \%$ agarose gels using QIAquick Gel Extraction Kit (Qiagen) according to the manufacturer's instructions, and cloned into pGEM-T Easy (Promega), by incubating the reaction with T4 DNA Ligase (pGEM T-Easy Vector System, Promega). Inserts were sequenced on an ABI3700 (Perkin Elmer) sequencer.

To amplify the 5'-and 3'-UTR regions of dmrt1 and sox 9 genes, we performed the RNA ligase-mediated rapid amplification of 5' and 3' cDNA ends using the GeneRacer Kit (Invitrogen) according to the manufacturer's instructions. All primers used are listed in Table 1.

\section{Sequence analysis}

The multiple alignment software Clustal X was employed for alignment of nucleotide sequences and their deduced amino acid sequences, and also to calculate and display the phylogenetic trees using the N-J method. The values represent bootstrap scores of 1,000 trials, indicating the credibility of each branch. The computer programs Clustal $\mathrm{X}$ and Boxshade [49] were used to construct the figures.

Accession numbers of the dmrt1 and sox 9 sequences are as follows: 1) dmrt1: Silurus meridionalis [EF015487], Clarias gariepinus (AF439561), Danio rerio [NM_205628.1], Acipenser transmontanus [AY057061], Tetraodon nigroviridis [AY152820], Takifugu rubripes [NM_001037949], Odontesthes bonariensis [AY319416], Xiphophorus maculatus [AF529187], Oryzias latipis [AF319994], Oncorhynchus mykiss [AF209095], Oreochromis niloticus [AF203489], Acanthopagrus schlegelii [AY323953], Homo sapiens [AF130728], Mus musculus [NM_015826], Canis familiaris [XM_846402], Gallus gallus [AF123456], Pelodiscus sinensis [AB179697]; 2) sox9: Danio rerio a [NM_131643.1], Danio rerio b [NM_131644.1], Takifugu rubripes a [AY277964.1], Takifugu rubripes b [AY277965.1], Monopterus albus a1 [AF378150.1], Monopterus albus a2 [AF378151.1], Oryzias latipis a [AY870394.1], Oryzias latipis b [AY870393.1], Oncorhynchus mykiss [AB006448.1], Oncorhynchus mykiss alpha2 [AF209872.1], Oreochromis niloticus a [DQ632574.1], Oreochromis niloticus b [DQ632575.1], Gasterosteus aculeatus [AY351914.1], Mus musculus [AF421878.1], Gallus gallus [U12533.1]. The nucleotide and amino acid sequences used in the phylogenetic analysis were obtained from GenBank [50].

\section{Real-time, quantitative PCR (qRT-PCR)}

Relative A. altiparanae dmrt1 and sox9 mRNA expression levels were assessed by qRT-PCR in the Applied Biosystems 7300 Real-Time PCR System (Applied Biosystems). The primers for qRT-PCR amplification (Table 1) were designed with Primer Express version 3.0 software (Applied Biosystems). The final reaction mixture contained of $3 \mu \mathrm{L}$ of each primer $(0.4 \mathrm{mM}), 6 \mu \mathrm{L}$ of $\mathrm{SYBR}^{\circ}$ Green PCR Master Mix (Applied Biosystems), and $3 \mu \mathrm{L}$ cDNA reverse transcribed from a standardized amount of total RNA $(2 \mu \mathrm{g})$. All quantitative reactions were subjected to: $95^{\circ} \mathrm{C}$ for $10 \mathrm{~min}$ followed by 40 cycles at $95^{\circ} \mathrm{C}$ for $15 \mathrm{sec}$ and $60^{\circ} \mathrm{C}$ for $1 \mathrm{~min}$, and, at the end, $95^{\circ} \mathrm{C}$ for $15 \mathrm{sec}$. Melting curve analysis was applied to all reactions to ensure homogeneity of the reaction product. Potential contamination was assessed by including notemplate controls, with no products being observed in these reactions. Dilution curves generated by serial dilutions (1:10) of cDNA were used to calculate amplification efficiencies. Transcript levels of the target genes were normalized against the lambari efla gene using primers derived from the $D$. rerio ef1a sequence [51]. All 
Table 1 Sequence of primers used in the present study

\begin{tabular}{|c|c|c|}
\hline Primer & Sequence & Purpose \\
\hline Dmrt1 I-F & 5'-TGCAGAAACCACGGCTTC-3' & CDNA fragment PCR \\
\hline Dmrt1 I-R & 5'-GATGCCCATCTCCTCCTC-3' & CDNA fragment PCR \\
\hline Dmrt1 ॥-F & 5'-GGCAGTCCCTCCAGTTACAG-3' & cDNA fragment PCR \\
\hline Dmrt1 II-R & 5'-GGGAGGGCTGGTAAAAGTTG-3' & cDNA fragment PCR \\
\hline Dmrt1 III -R & 5'-GRGACAYGTTRTGGCTGGAC-3' & CDNA fragment PCR \\
\hline Sox9 I-F & 5'-GAAGGACCATCCCGACTACA-3' & CDNA fragment PCR \\
\hline Sox9 I-R & 5'-GKGTRTACATKGGCCTCTGG-3' & cDNA fragment PCR \\
\hline Sox9 II-F & 5'-CGAACGTGTTCGGGAACTTA-3' & cDNA fragment PCR \\
\hline Sox9 II-R & 5'-GGCGTGGCTGTAGTAGGAGT-3' & CDNA fragment PCR \\
\hline Dmrt1 5UTR & 5'-AGAGCCACCTGAGCGGCCATGACCC-3' & RACE \\
\hline Dmrt1 3UTR & 5'-GCCTACTACAGCAACCTCTACAATTATCAGCAATACCA-3' & RACE \\
\hline Sox9 5UTR I & 5'-GCACGAGGATCTCTTCCCCCTTAGTTTCTACGCATTTT-3' & RACE \\
\hline Sox9 5UTR ॥ & 5'-GCTCCGCGTTGTGCAGATGCGGGTACTGGT-3' & RACE \\
\hline Sox9 3UTR & 5'-CGCATCTGCACAACGCGGAGCTCAGCAA-3' & RACE \\
\hline Dmrt1-RT-F & 5'-CAGCCTACTACAGCAACCTCTACAAT-3' & qRT-PCR \\
\hline Dmrt1-RT-R & 5'-TGGCTGGACAGACGGCTATC-3' & qRT-PCR \\
\hline Sox9-RT-F & 5'-CCAGCATGGGCGAAGTG-3' & qRT-PCR \\
\hline Sox9-RT-R & 5'-CGTCGGTGGCGTTGGA-3' & qRT-PCR \\
\hline Ef1a-RT-F & 5'-CTTCTCAGGCTGACTGTGC-3' & qRT-PCR \\
\hline Ef1a-RT-R & 5'-CCGCTAGCATTACCCTCC-3' & qRT-PCR \\
\hline$\beta$-Actin-F-Control & 5'-CCATCTCCTGCTCGAAGTC-3' & Internal control \\
\hline$\beta$-Actin-R-Control & 5'-CACTGCCCATCTACGAG-3' & Internal control \\
\hline
\end{tabular}

the primers used for qRT-PCR were validated and the amplified fragments were sequenced. The $\Delta \mathrm{Ct}$ values presented as means \pm standard error of the mean (SEM), were analyzed by one way ANOVA, Tukey's and Student's t test. A significance level of $\mathrm{P}<0.05$ was used for all tests.

\section{Results}

Sequence analysis of $A$. altiparanae dmrt 1 and sox 9 cDNAs

The isolated dmrt1 cDNA is 1855 bp long, with an open-reading frame (ORF) of $864 \mathrm{bp}$, encoding a 287 aa protein (GenBank accession no. KM502983). Lambari Dmrt1 displays all three characteristic domains that are conserved in other vertebrate Dmrt1 proteins (Figure 1). The DNA-binding domain is 62 aa long and shows less divergence than the male-specific domain (20 aa) and the $\mathrm{P} / \mathrm{S}$ rich region (29 aa) compared with other species. The complete protein sequence of lambari's Dmrt1 exhibits high similarity with the African catfish (74\%) and the zebrafish (74\%). A phylogenetic tree was designed by comparing the amino acid sequence of the Dmrt1 of $A$. altiparanae with 17 Dmrt1 sequences from different vertebrate groups using fugu Dmrt2 sequence as the outgroup (Figure 2). The tree shows a high homology of $A$. altiparanae Dmrt1 with the Southern and African catfish, all belonging to the superorder Ostariophysi.

The isolated $A$. altiparanae sox 9 cDNA is 1,533 bp long, and encodes a 483 aa polypeptide, containing the characteristic 78 aa Sox9-HMG domain and the 104 aa transactivation domain (GenBank accession no. KM502984). It shares high similarity with African catfish (78\%), sturgeon (74\%) and rainbow trout (76\%). As shown in Figure. 3, the fragment displays high similarity in the HMG-domain when comparing the Sox9 protein to other clades. The tree constructed in Figure 4 demonstrates that the gene belongs to the Sox 9 subfamily, closely related to teleost fish.

Since the genome of the cave fish, Astyanax mexica$n u s$, was released, the sequence of both dmrt1 and sox 9 of lambari can be compared with another Characidae species. The Dmrt1 protein sequence has $98 \%$ similarity between both Astyanax species, showing a high conservation of it sequence (Figure 5A). The Sox9 protein of lambari presents $98 \%$ identity with Sox9B and $72 \%$ with Sox9A of cave fish (Figure 5B).

\section{Gonad development}

Following the gonad development of Astyanax altiparanae starting at $5 \mathrm{dah}$, it was possible to find primordial 
germ cells along the anterior-posterior axis of the genital ridge (Figure 6A). In animals collected before 58 dah only undifferentiated gonads were observed (Figure 6B). At 58 dah, the first sign of gonad formation was found, with the formation of ovaries, where primary oocytes are cleared recognized (Figure $6 \mathrm{C}$ ). At this time on, undifferentiated gonad was also observed, which later will give rise to the male. The first sign of testis formation was found at 73 dah, presenting the germ cells in cysts, and some in already advanced spermatogenesis stages. However, no sperm was observed in the lumen of the tubules, indicating that these animals were not sexually mature (Figure 6D).

\section{Gene expression analysis of dmrt 1 and sox 9}

In all larval stages of lambari, no expression of dmrt 1 was observed. The expression of $\operatorname{sox} 9$ is relatively high at 5 dah, and is then down-regulated between 5 dah and 12 dah. Expression stays low up to the 26 dah stage, until at 33 dah a significant increase in expression occurs $(p<0.05)$ (Figure 6E). In the juvenile gonad, the mRNAs of dmrt1 and sox 9 are both detected at 58 dah and 


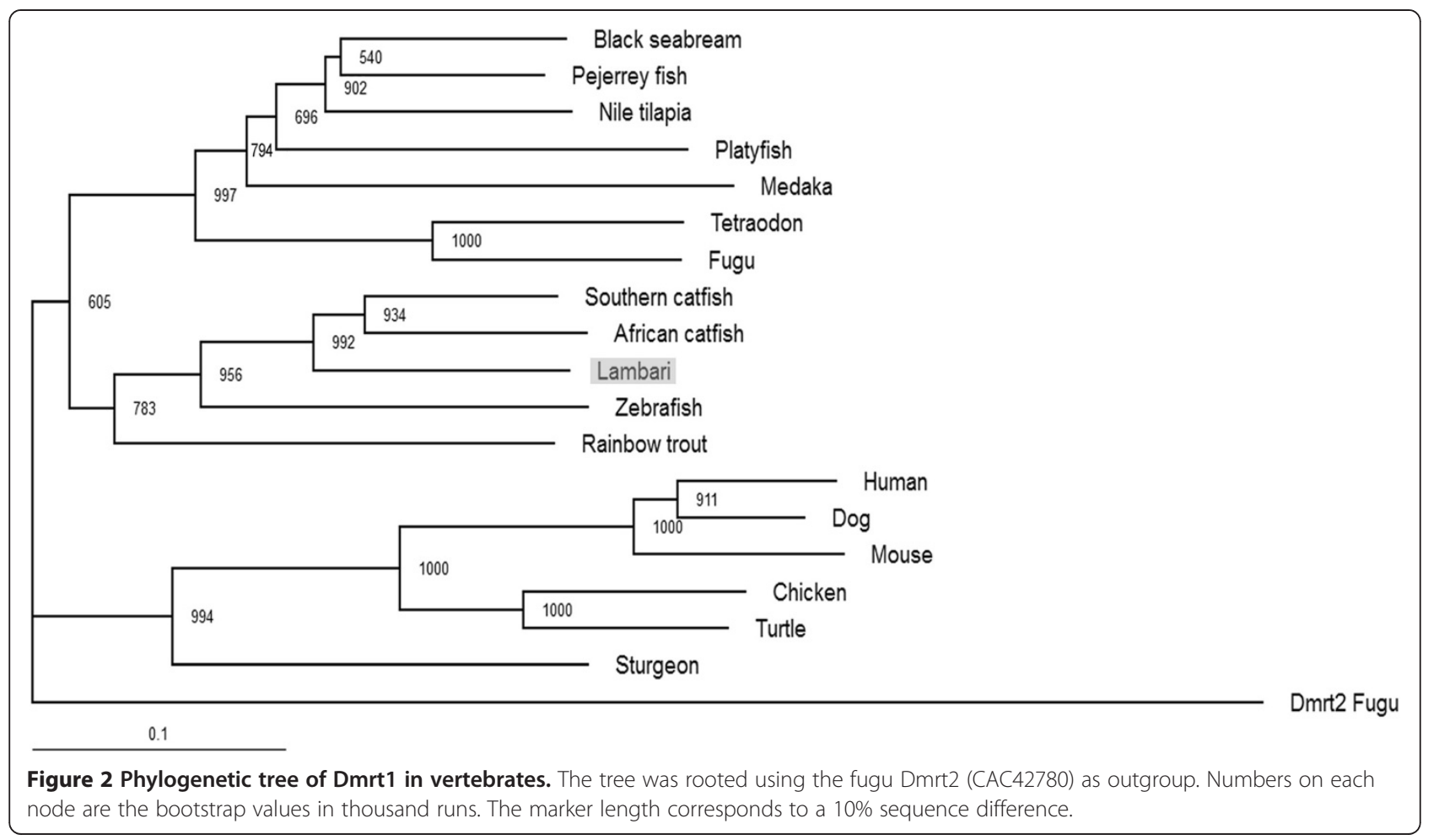

increase at 73 dah, with only $d m r t 1$ presenting statistical significance $(p<0.05)$ (Figure 6F). These data correlate with the morphological analysis, in which the presence of testicular tissue was found at 73 dah.

In adult tissues of $A$. altiparanae we found gonad specific expression of dmrt1, with higher expression in testis, displaying more than 200-fold higher expression than the ovary (Figure 7A). sox 9 relative mRNA expression was detected in gills, gut and brain in both males and females sexes. At the level of the gonads, sox 9 expression is male specific. Significant differences in expression levels were observed with higher expression in female than in male tissues, eg brain and gills $(p<0.05)$ (Figure 7B).

Following the annual reproductive cycle of lambari male as described by Costa et al. [47], we collected four phases of testicular maturation: early GE development (Figure 8A), mid GE development (Figure 8B), late GE development (Figure 8C) and regressed (Figure 8D). Analyzing the expression of $d m r t 1$ we observed a peak of expression in the late GE development phase, but at the other phases the expression is maintained at the same low level (Figure 8E). For sox 9 expression, there is a significant upregulation in the mid and late GE development phases (Figure 8F).

\section{Discussion}

Fish display high diversity of sexual differentiation strategies $[3,52]$. Therefore, it is important to study the molecular mechanism of sex determination. Brazil is known for its high abundance of fish species, and the Astyanax genus is widely distributed throughout the neotropical territories. However, information about sex determination of this group is still scarce in the literature. In the present study, the complete mRNA sequence of dmrt1 and sox 9 of Astyanax altiparanae were cloned, and their expressions were analyzed during stages of gonad development and throughout the male reproductive cycle.

This group of fish displays high diversity of chromosomal systems, but no sex chromosome was described for A. altiparanae, indicating absence of genetic sex determination or homomorphic sex chromosomes [53]. The doublesex and mab-3 transcription factor 1 gene was shown to be conserved during evolution, as described in mammals, reptiles, amphibians, fish and invertebrate [19-24,54]. Analyzing the DM domain structure and the phylogenetic tree of the deduced Dmrt1 amino acid sequence of lambari, we found that its sequence is similar to species that belong to the Superorder Ostariophysi. The Ostariophysi is composed by four orders: Characiformes (tetras, piranhas), Siluriformes (catfishes), Cypriniformes (carps, zebrafish) and Gymnotiformes (electric fish). The DM domain of lambari varies in only one amino acid, when compared with other vertebrate species (A-S). Interestingly this same amino acid is changed in fugu (A-V). However, this amino acid change is conservative in fugu, but this is not the case for A. altiparanae. Biochemical 
experiments have to be done to see if this single change has an influence on the DNA-binding properties of the protein.

The dmrt1 gene is not only characterized by its DMdomain, but also by its male-specific region. Two types of DSX genes are present in Drosophila, namely the male type $\left(\mathrm{DSX}_{\mathrm{m}}\right)$ and the female type $\left(\mathrm{DSX}_{\mathrm{f}}\right)$. The male-specific motif is present only in the $\mathrm{DSX}_{\mathrm{m}}$. The male specific motif has also been characterized by molecular cloning in vertebrates [21,24,33]. By molecular cloning of lambari dmrt1, we collected additional evidence of the evolutionary conservation of this domain, since only two amino acid changes were observed when compared with the African catfish sequence.

More than one isoform of $d m r t 1$ in fish species have been described [24,25]. Liu et al. [24] described an alternative splicing isoform of $d m r t 1$, with the DM domain being similar for both isoforms. Although only one isoform was isolated in the present work, it is possible that more isoforms may be found in Astyanax altiparanae. 


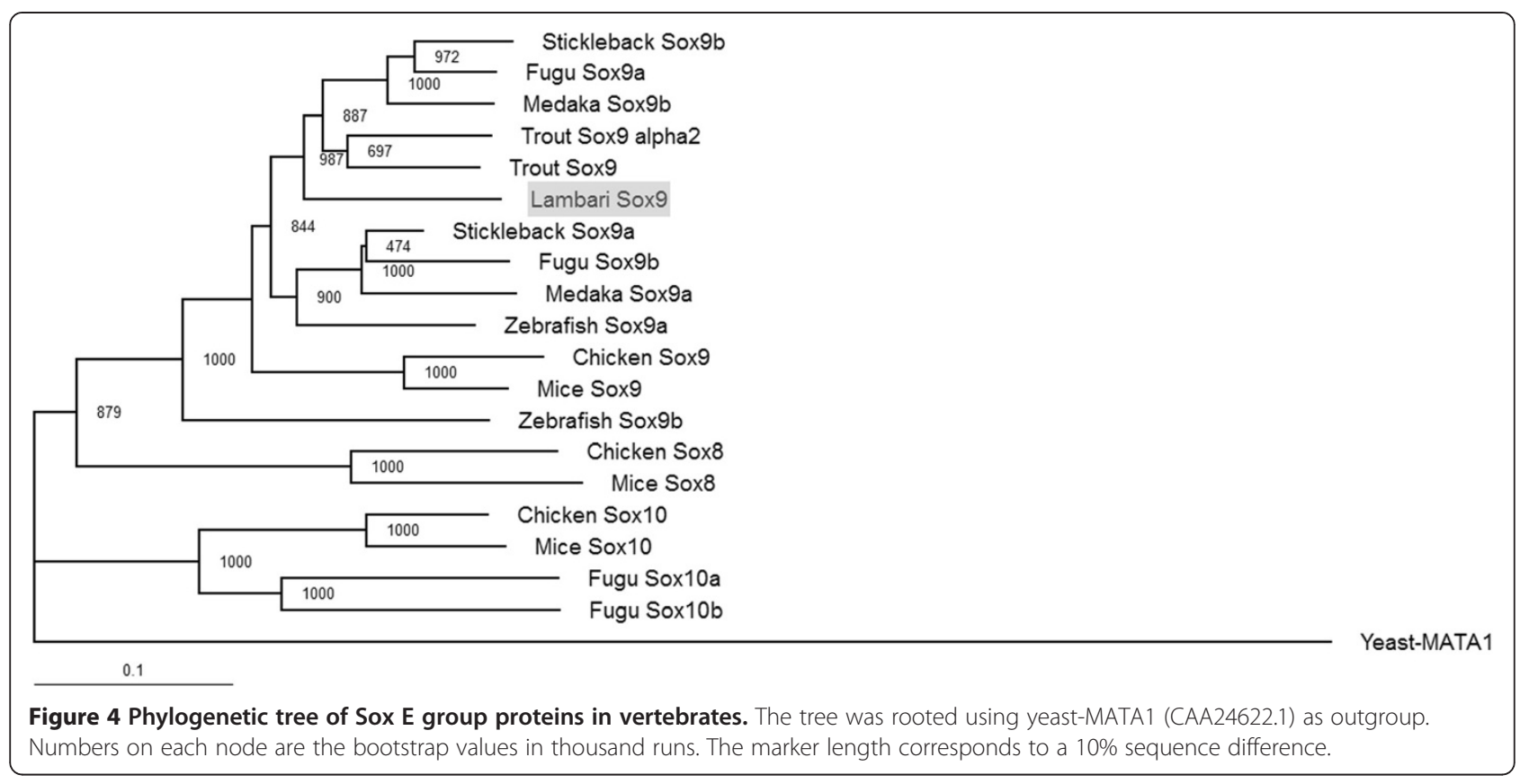

\section{A Dmrt1}

Lambari 1 MSDEEQAKQQQFVDVSSPLSPAPGGRRQPRMPKCSRCRNHGFVSPLKGHKRFCNWRDCQCQKCKLISERQRVMAAQVALRRQQAQEEEMGICTPVNLSGNDIVVKNEPSNDFVFPVGTRS

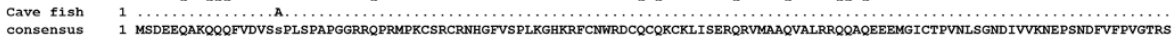

Lambari 121 PSATSPTAS----GRSTLSPGPTSSSRGHSDASTDLMVDASYYNFYQPSRYPAYYSNLYNYQQYQQMPNGDSRLSSHNVSQQYRMHYYSAASYLSQGLGTSACVPPIFTLEENNACPEPK

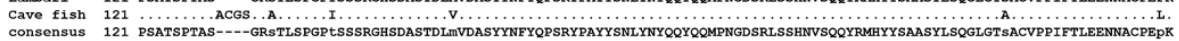

Lambar1 237 TAAFSADGAHDTSLTCMSINPMVNADNKPECEANSDSGAFSVDSIIEGAAK

Consensus 241 TaAFSADGAADTSLTCMSINPMYNADNKPECEANSDSGAFSVDSIIEGAAK

\section{B Sox9}

$\begin{array}{ll}\text { Lambari } & 1 \text { MNLLDPYVKMTDDRDKCLRDAPSPGMDSEDSGAASPCPSGSGSDTENTRPTDNHDDFKKDD-EERFPVCIRDAVSQVLKGYDWTLVPMPVRVNGSSKNKRPHVKRPMNAFMVWAQAARRKL } \\ \text { Cave } \mathrm{f} \text { ish a } & 1\end{array}$ \begin{tabular}{l} 
Cave fish a \\
Cave $f$ ish $b$ \\
\hline
\end{tabular}

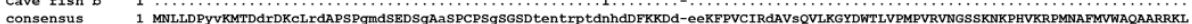

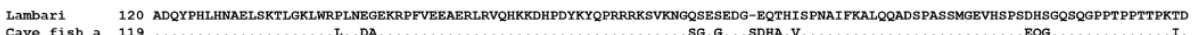

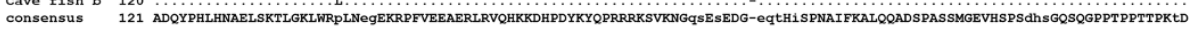

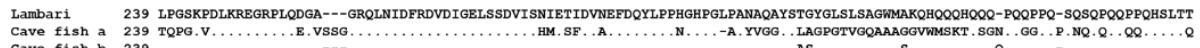
(1)

Cave

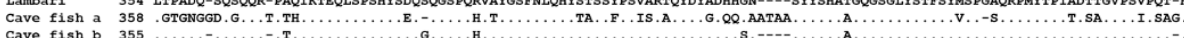

consensus 361 Ltpadq-sQsQQR-PaqIKTEQLSPSHYSdQSQGSPQVVaYGSFNLQHYstSSYPSVaRtQYDYaDhhgn----sYYSHAtGQGSGLYSTFSYmSPgaQRPMYTPIaDttGVPSVPqt-H

$\begin{array}{lll}\text { Lambari } & 467 \text { SPQHWEQQPVYTQLSRP } \\ \text { Cave fish a } & 476\end{array}$

$\begin{array}{llll}\text { Cave fish b } & 468 \\ \text { consensus } & 481 & \ldots \ldots \ldots \ldots \ldots \ldots \ldots \\ \text { sPQHWeQpUYTQLSRP }\end{array}$

Figure 5 Comparison of the deduced aa alignments of Dmrt1 (A) and Sox9 (B) proteins of Astyanax altiparanae and Astyanax mexicanus. 

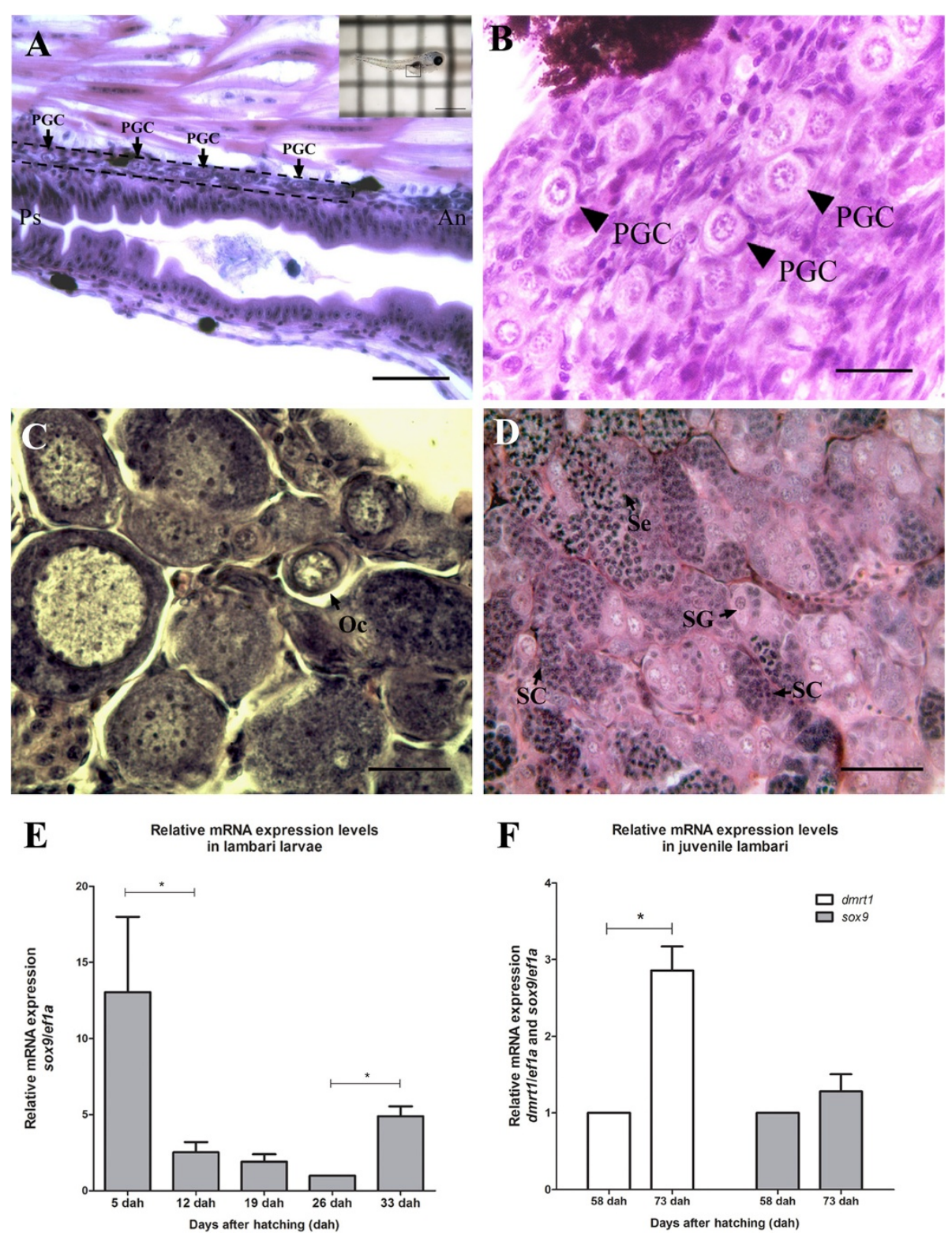

Figure 6 Gonad development of A. altiparanae (A). Longitudinal view of a 5 dah larva; scale bar $=50 \mu \mathrm{m}$; region indicated by a square in the photography (B) Undifferentiated gonad of a 40 dah juvenile; scale bar $=20 \mu \mathrm{m}$. (C) Juvenile ovary at 58 dah; scale bar $=50 \mu \mathrm{m}$. (D) Male testis of 73 dah; scale bar $=50 \mu \mathrm{m}$. (E) sox9 mRNA expression in larvae of lambari in different stages of development. Values are expressed as arbitrary units of sox9 mRNA normalized against the expression levels of ef1a amplified from the same template, relative to the expression observed in 26 dah. (F) dmrt1 and sox9 mRNA expression of juvenile lambari. Values are expressed as arbitrary units of both mRNA levels normalized against the expression levels of efla amplified from the same template, relative to the expression observed in 58 dah. The asterisk indicates significant difference $(\mathrm{p}<0.05)$ after a Student's t test comparing the developmental stages indicated. An, anterior region of the larva; Oc, oocyte; Ps, posterior region of the larva; PGC, primordial germ cell; SC, spermatocyte; Se, Sertoli cell; SG, spermatogonia.

The sox 9 gene is another sex determination related gene, which has been well described in mammals. However, this gene is also important for cartilage formation $[34,35,55]$. This gene also contains a DNA binding domain, known as HMG domain, which is characteristic of the Sox family [56,57]. By sequence comparison, we found that the $\operatorname{sox} 9$ gene from Astyanax altiparanae belongs to the SoxE subfamily. Analysis of gene sequences and of the Sox9 phylogenetic tree shows that Astyanax altiparanae clusters in the basal teleost fish, confirming the previously described morphological data. Another characteristic of the Sox 9 protein is the presence of the transactivation domain in the $\mathrm{C}$-terminal region. This domain is also conserved being rich in proline, glutamine and serine. Mutations in this transactivation domain lead to sex reversal in humans, suggesting that mutations 
A

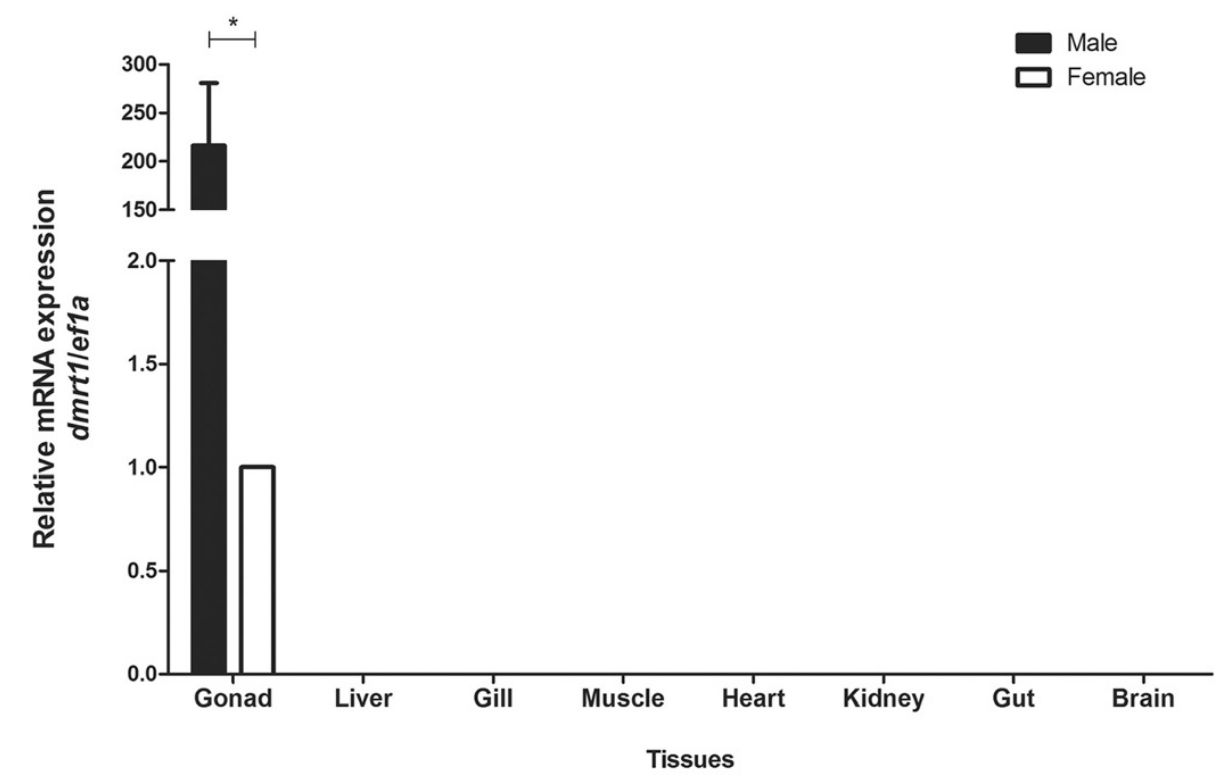

B

Tissue specific expression of sox9 in adult lambari

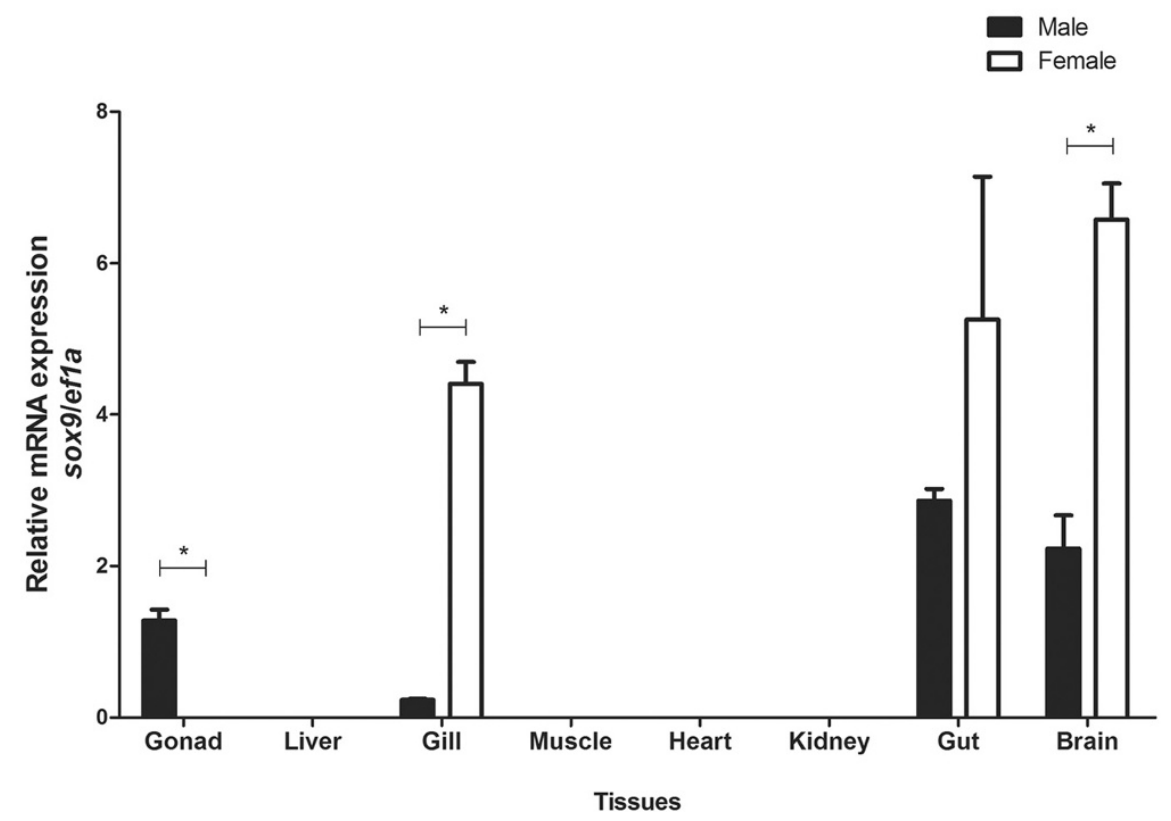

Figure 7 Tissue specific dmrt1 (A) and sox 9 (B) expression in adult lambari. Values are expressed as arbitrary units of both mRNA levels normalized against the expression levels of efla amplified from the same template and relative to the expression observed in female gonads (A) and to the average expression observed in gills of male and female (B). The asterisk indicates a significant difference $(p<0.05)$ after a Student's $t$ test comparing the expression between male and female gonads.

probably inhibit transactivation of sox9 downstream genes in mammals [58]. Analyzing the transactivation domain of lambari, we show a high degree of similarity with other teleost fish, particularly, with the sox $9 b$ gene copy.
It has been proposed that gene duplication facilitates the evolution of gene functions, via mechanisms of neofunctionalization and subfunctionalization [59]. Some human gene families demonstrate the history of two 

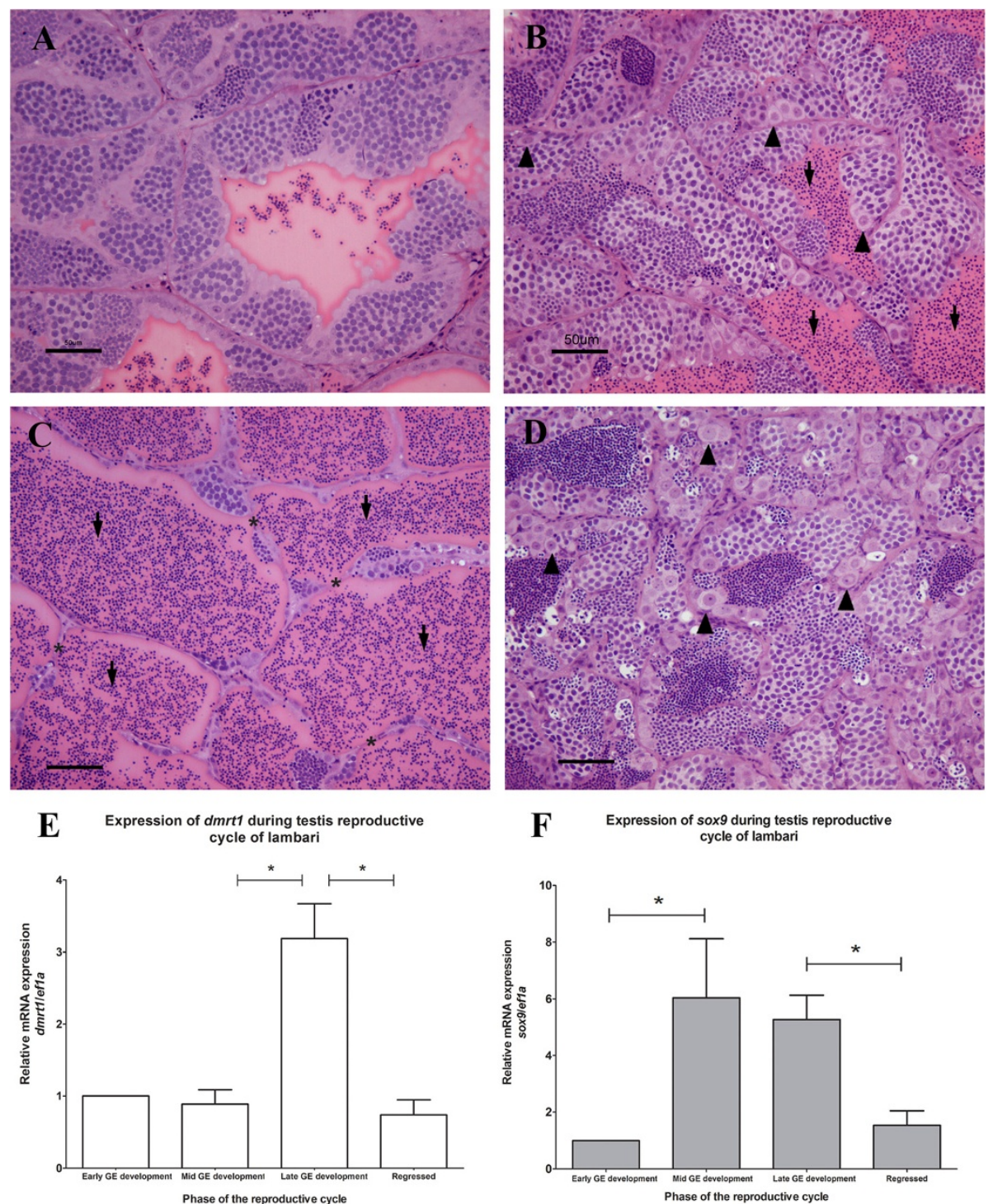

F

Expression of sox9 during testis reproductive
cycle of lambari

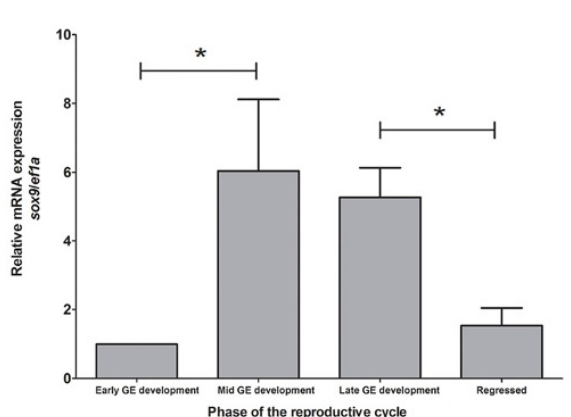

Figure 8 Testes of A. altiparanae in different phases of annual reproductive cycle. (A) Early GE development: continuous GE with cysts in different phases of spermatogenesis and low amount of free germ cell in the lumen (arrow); (B) Mid GE development: discontinuous GE, with some spermatogonia (arrowhead) and several free germ cells in the tubule lumen (arrow). (C) Late GE development: where discontinuous GE (*) could be found with a great amount of free cells immersed in the secretion found in the tubule lumen (arrow). (D) Regressed phase: high amount of spermatogonia (arrowhead) and Sertoli cells in the GE. Relative mRNA expression levels of dmrt1 (E) and sox9 (F) during different testes maturation phases. Values are expressed as arbitrary units of both mRNA levels normalized against the expression levels of efla amplified from the same template and relative to the expression observed during early GE development. Scale bar $=50 \mu \mathrm{m}$.

rounds of gene duplication during early vertebrate evolution, and fish genomes have often two co-orthologs for many human genes, as a result of a third round of genome duplication that occurred at the base of the teleost radiation [60]. Cresko et al. [61] described in zebrafish that the combined expression pattern of the two sox 9 genes approximately corresponds to that of the single Sox9 in mouse, which is indicative of a partitioning of an ancestral function. In this work we isolated only one copy of sox9 in lambari, derived from testis samples, which also showed male specific expression in gonads.
The genome of $A$. mexicanus provides us a predicted sequence of a second copy of the sox 9 gene, and together with our phylogenetic analyses, the sox 9 gene of lambari shows higher identity with other teleost $s 0 x 9 b$ genes. However, the presence of another sox 9 gene copy in lambari can only be confirmed by isolation and characterization of this gene in this species. The $\operatorname{sox} 9 a$ and $\operatorname{sox} 9 b$ of zebrafish are more divergent in comparison to other teleost sequences, and even lambari being closer phylogenetically to zebrafish, the Sox9 sequence does not cluster together with the zebrafish sequence. But the sequence of Sox9 from 
lambari still clusters in the group of basal teleost, going along with morphological analyses [62].

The pattern and timing of gonad differentiation and sex determination have been studied in fish [63-68]. In most gonochoric teleost species, the ovary develops first while in male the gonad remains undifferentiated and a few days, weeks or even months later the formation of testis occurs $[67,68]$. Apparently, this pattern is observed during the development of lambari gonads, with the first sign of ovary (at 58 dah) being observed in female. In males the gonad remains undifferentiated. Only two weeks later the testis formation was observed in males (at 73 dah). However, the testes showed some cysts in advanced stages, indicating that the formation of the organ occurred sometime before that observed. The origin of germ cells occurs independently from the gonadal tissue, and, during development, these cells migrate to the genital ridge [69-71]. The histological analysis of gonads during lambari development showed that at 5 dah the germ cells are already located in the genital ridge, where the future gonad will be located.

During gonad development, the exact timing of dmrt1 and sox 9 expression and sex determination varies between species, but, in general, their expression is correlated to the formation of testis [72]. In zebrafish and medaka, the onset of dmrt1 expression occurs in the first days after hatching (10 dah), and in medaka this gene is the first that is differentially expressed, when male and female are compared [73,74]. The dmrt1 gene has been shown to be the main sex determination gene, being critical for male determination [75]. In lambari, the expression of $d m r t 1$ was just observed in the juvenile gonads where no testis structure was observed (at 58 dah), indicating that the role of dmrt1 in the testis is most likely prior to visible sex differentiation.

In amniotes, the expression of dmrt1 is restricted to gonads, being more highly expressed in testis than in ovary. Our data go together with other fish species, where the expression of $d m r t 1$ is apparently restricted to gonads, similarly to amniotes. The testicular form of sox 9 is an upstream gene in the sex differentiation cascade being conserved in vertebrates [57]. In the gonad of lambari, the sox 9 expression is male-specific. However, our data show expression of sox 9 in other adult tissues of lambari not only in gonad, a result that has also been observed in zebrafish $[42,74]$. However, the higher expression of sox 9 observed in gut of both males and females and the higher expression in female gills when compared to male gills, are totally uncommon in fish (Table 2). In chicken and Lepidochelys olivacea turtle, Sox9 expression was identified in undifferentiated gonads, being upregulated during testis formation, and downregulated when it differentiates into ovary $[76,77]$. The function of sox9 in fish gonad differentiation remains unknown. In zebrafish, a high expression of the sox $9 a$ variant has been shown during gonadal differentiation to male [74]. In medaka no sox9 expression was shown in the early developing gonad, when comparing male and female embryos. This shows that the role of this gene is not related to the early sex determination in medaka [78]. In lambari, there is also no difference of sox 9 expression before and after the differentiation of testis, indicating that $d m r t 1$ is apparently more crucial for this role than sox9. However, the expression level of sox 9 is already observed in the larvae of lambari, showing higher levels at 5 dah, being down-regulated at 12 , 19 and 26 dah. Since the expression levels of sox 9 was determined from the whole larvae body, those early expression levels are not necessarily related to gonad formation or sex determination. To confirm if the expression pattern of dmrt1 and sox 9 in adults and during the development of the gonad is directly related to sex determination and differentiation, future functional experiments have to be performed.

The morphology of $A$. altiparanae testis shows that during the annual reproductive cycle the male gonad passes through complex changes in the structure of the germinal epithelium [47]. Our data show that the expression pattern of dmrt1 and sox 9 also change during the process of gonad maturation, especially at the late GE development phase, where the lumen was filled with spermatids and spermatozoa. In tilapia with dmrt1-deficient testes, a significant testicular regression was observed including deformed efferent ducts, degenerated spermatogonia or even loss of germ cells, and proliferation of steroidogenic cells [79]. In medaka, a loss-of-function mutation in $d m r t 1$ leads to a complete male-to-female sex reversal during the phase of maintenance of the gonad [80]. Expression analyses of $d m r t 1$ in rainbow and pejerrey during the different spermatogenesis stages showed a similar situation in lambari, where dmrt1 expression is extremely decreased after spermiation. Analysis of medaka $s o x 9 b$ reveals that this gene has a important role in the germ cell maintenance in males and females, which could explain the differences of lambari sox9 gene expression throughout the testis maturation cycle [81].

\section{Conclusions}

The lambari dmrt1 and sox 9 gene sequences are conserved and are closely related to sequences of other basal teleosts. Expression analysis of both genes revealed testis specificity, indicating that these genes display male-specific functions in the adult lambari, probably in gonad maintenance. The expression patterns of dmrt1 and sox 9 change throughout the reproductive cycle of male, with a significant down-regulation after spermiation, indicating a possible role in spermatogenesis. During gonad formation, the differentiation of the ovary begins earlier than testis, with an upregulation of dmrt1 
Table 2 Gene expression of sox9a and sox $9 b$ in adult tissues of different teleost specie

\begin{tabular}{|c|c|c|c|c|c|c|c|c|c|c|c|c|c|c|c|c|c|c|}
\hline & \multicolumn{2}{|c|}{ Liver } & \multicolumn{2}{|c|}{ Gills } & \multicolumn{2}{|c|}{ Muscle } & \multicolumn{2}{|c|}{ Heart } & \multicolumn{2}{|c|}{ Kidney } & \multicolumn{2}{|c|}{ Gut } & \multicolumn{2}{|c|}{ Brain } & \multicolumn{2}{|c|}{ Testis } & \multicolumn{2}{|c|}{ Ovary } \\
\hline & sox9a & sox9b & sox9a & sox9b & sox9a & sox9b & sox9a & sox9b & sox9a & sox9b & sox9a & sox9b & sox9a & sox9b & sox9a & sox9b & sox9a & sox9b \\
\hline Astyanax altiparanae & \multicolumn{2}{|c|}{-} & \multicolumn{2}{|c|}{++} & \multicolumn{2}{|c|}{-} & \multicolumn{2}{|c|}{-} & \multicolumn{2}{|c|}{-} & \multicolumn{2}{|c|}{++} & \multicolumn{2}{|c|}{++} & \multicolumn{2}{|c|}{+} & \multicolumn{2}{|c|}{ - } \\
\hline Oncorhynchus mykiss* & \multicolumn{2}{|c|}{+} & \multicolumn{2}{|c|}{ N.R. } & \multicolumn{2}{|c|}{ N.R. } & \multicolumn{2}{|c|}{+} & \multicolumn{2}{|c|}{ N.R. } & & R. & \multicolumn{2}{|c|}{+} & \multicolumn{2}{|c|}{+} & \multicolumn{2}{|c|}{+} \\
\hline Oryzias latipes & - & - & + & + & - & - & - & + & - & - & & R. & ++ & ++ & + & +++ & +++ & - \\
\hline Danio rerio & - & - & + & + & + & - & + & - & + & + & & R. & ++ & + & ++ & - & - & +++ \\
\hline
\end{tabular}

N.R., data not reported.

"Data of rainbow trout sox9. 
at 78 dah, when the first testis structures can be recognized. This indicates that the male sex determination period occurs before this stage. In larvae, no expression of dmrt1 is observed, but the sox 9 gene expression is downregulated at 12 dah, and is upregulated at 33 dah. Future functional experiments can help to confirm the role of dmrt1 and sox9 genes in the sex determination, differentiation and male reproductive cycle in Astyanax altiparanae.

\author{
Abbreviations \\ DMRT1: Doublesex/mab-3 related transcription factor-1; DSX: Doublesex; \\ EF1a: Elongation factor-1 alpha; GE: Germinal epithelium; HMG: High mobility \\ group; ORF: Open reading frame; SOX9: SRY-box 9; SRY: Sex determining \\ region of $Y$.
}

\section{Competing interests}

The authors declare that they have no competing interests.

\section{Authors' contributions}

MCA carried out the molecular analyzes, sampling of the larvae and juveniles, statistical analysis and drafted the manuscript. ACOC and MCS supervised the molecular analyses, and helped to draft the manuscript. LWOJ collaborated with the molecular analyses and participated in the sampling of adult animals. JB conceived the molecular genetic studies and participated in the design of the study. RMF performed all histological preparation. MS conceived of the study and helped to draft the manuscript. MIB defined the research theme, coordinated all steps of the study and reviewed all version of the manuscript. All authors read and approved the final manuscript.

\section{Acknowledgements}

This work was supported by Fundação de Amparo a Pesquisa do Estado de São Paulo (2009/07010-6). Special thanks to Fabiano Gonçalves Costa, Daniel Liedtke and Amaury Herpin for support and critical discussions. We also thank the Aquiculture and Hydrobiology Station of Paraibuna for providing the lambari fish and to Cruz Alberto Mendoza Rigonatti for technical support.

\section{Author details \\ 'Department of Cell and Developmental Biology, Institute of Biomedical Science, University de São Paulo, São Paulo, SP, Brazil. ${ }^{2}$ Department of Physiological Chemistry I, University of Würzburg, Am Hubland, Würzburg, Germany. ${ }^{3}$ Chemistry Institute, Biochemistry Department, Cell and Molecular Therapy Center (NUCEL-NETCEM), School of Medicine, University of São Paulo, São Paulo, SP, Brazil. ${ }^{4}$ Department of Biology, Faculty of Science, Utrecht University, Utrecht, The Netherlands.}

Received: 19 September 2014 Accepted: 5 January 2015 Published: 11 January 2015

\section{References}

1. Graham P, Penn JK, Schedl P. Masters change, slaves remain. Bioessays. 2003;25:1-4

2. Koopman P, Gubbay J, Vivian N, Goodfellow P, Lovell-Badge R. Male development of chromosomally female mice transgenic for Sry. Nature. 1991;351:117-21

3. Capel B. Sex in the 90s: SRY and the switch to the male pathway. Annu Rev Physiol. 1998;60:497-523.

4. Temel SG, Gulten T, Yakut T, Saglam H, Kilic N, Bausch E, et al. Extended pedigree with multiple cases of XX sex reversal in the absence of SRY and of a mutation at the SOX9 locus. Sex Dev. 2007;1:24-34.

5. Hayashi Y, Kobira H, Yamaguchi T, Shiraishi E, Yazawa T, Hirai T, et al. High temperature causes masculinization of genetically female medaka by elevation of cortisol. Mol Reprod Dev. 2010;77:679-86.

6. Kobayashi T, Kajiura-Kobayashi H, Guan G, Nagahama Y. Sexual dimorphic expression of DMRT1 and Sox9a during gonadal differentiation and hormone-induced sex reversal in the teleost fish Nile tilapia (Oreochromis niloticus). Dev Dyn. 2008;237:297-306.
7. Liu ZH, Zhang YG, Wang DS. Studies on feminization, sex determination, and differentiation of the Southern catfish, Silurus meridionalis-a review. Fish Physiol Biochem. 2010;36:223-35.

8. Yamaguchi T, Yoshinaga N, Yazawa T, Gen K, Kitano T. Cortisol is involved in temperature-dependent sex determination in the Japanese flounder. Endocrinology. 2010;151:3900-8.

9. Hattori RS, Murai Y, Oura M, Masuda S, Majhi SK, Sakamoto T, et al. A Y-linked anti-Mullerian hormone duplication takes over a critical role in sex determination. Proc Natl Acad Sci U S A. 2012;109:2955-9.

10. Kamiya T, Kai W, Tasumi S, Oka A, Matsunaga T, Mizuno N, et al. A trans-species missense SNP in Amhr2 is associated with sex determination in the tiger pufferfish, Takifugu rubripes (fugu). PLoS Genet. 2012;8:e1002798.

11. Myosho T, Otake H, Masuyama H, Matsuda M, Kuroki Y, Fujiyama A, et al. Tracing the emergence of a novel sex-determining gene in medaka, Oryzias luzonensis. Genetics. 2012;191:163-70.

12. Yano A, Guyomard R, Nicol B, Jouanno E, Quillet E, Klopp C, et al. An immune-related gene evolved into the master sex-determining gene in rainbow trout, Oncorhynchus mykiss. Curr Biol. 2012;22:1423-8.

13. Matsuda M. Sex determination in the teleost medaka, Oryzias latipes. Annu Rev Genet. 2005;39:293-307.

14. Nanda I, Kondo M, Hornung U, Asakawa S, Winkler C, Shimizu A, et al. A duplicated copy of DMRT1 in the sex-determining region of the $Y$ chromosome of the medaka, Oryzias latipes. Proc Natl Acad Sci U S A. 2002;99:11778-83.

15. Matsuda M, Nagahama Y, Shinomiya A, Sato T, Matsuda C, Kobayashi T, et al. DMY is a Y-specific DM-domain gene required for male development in the medaka fish. Nature. 2002:417:559-63.

16. Herpin A, Adolfi MC, Nicol B, Hinzmann M, Schmidt C, Klughammer J, et al, Divergent expression regulation of gonad development genes in medaka shows incomplete conservation of the downstream regulatory network of vertebrate sex determination. Mol Biol Evol. 2013;30:2328-46.

17. Burtis KC, Baker BS. Drosophila doublesex gene controls somatic sexual differentiation by producing alternatively spliced mRNAs encoding related sex-specific polypeptides. Cell. 1989:56:997-1010.

18. Sinclair AH, Berta P, Palmer MS, Hawkins JR, Griffiths BL, Smith MJ, et al. A gene from the human sex-determining region encodes a protein with homology to a conserved DNA-binding motif. Nature. 1990;346:240-4.

19. Raymond CS, Shamu CE, Shen MM, Seifert KJ, Hirsch B, Hodgkin J, et al. Evidence for evolutionary conservation of sex-determining genes. Nature. 1998;391:691-5.

20. De Grandi A, Calvari V, Bertini V, Bulfone A, Peverali G, Camerino G, et al. The expression pattern of a mouse doublesex-related gene is consistent with a role in gonadal differentiation. Mech Dev. 2000;90:323-6.

21. Guan G, Kobayashi T, Nagahama Y. Sexually dimorphic expression of two types of DM (Doublesex/Mab-3)-domain genes in a teleost fish, the Tilapia (Oreochromis niloticus). Biochem Biophys Res Commun. 2000;272:662-6.

22. Marchand O, Govoroun M, D'Cotta H, McMeel O, Lareyre JJ, Bernot A, et al. DMRT1 expression during gonadal differentiation and spermatogenesis in the rainbow trout, Oncorhynchus mykiss. Biochim Biophys Acta. 2000;1493:180-7.

23. Shibata K, Takase M, Nakamura M. The Dmrt1 expression in sex-reversed gonads of amphibians. Gen Comp Endocrinol. 2002;127:232-41.

24. Liu Z, Wu F, Jiao B, Zhang X, Hu C, Huang B, et al. Molecular cloning of doublesex and mab-3-related transcription factor 1 , forkhead transcription factor gene 2, and two types of cytochrome P450 aromatase in Southern catfish and their possible roles in sex differentiation. J Endocrinol. 2007;194:223-41.

25. Guo Y, Cheng H, Huang X, Gao S, Yu H, Zhou R. Gene structure, multiple alternative splicing, and expression in gonads of zebrafish Dmrt1. Biochem Biophys Res Commun. 2005;330:950-7.

26. Schulz RW, Bogerd J, Male R, Ball J, Fenske M, Olsen LC, et al. Estrogen-induced alterations in amh and dmrt1 expression signal for disruption in male sexual development in the zebrafish. Environ Sci Technol. 2007:41:6305-10.

27. Raymond CS. Dmrt1, a gene related to worm and fly sexual regulators, is required for mammalian testis differentiation. Genes Dev. 2000;14:2587-95.

28. Ferguson-Smith M. The evolution of sex chromosomes and sex determination in vertebrates and the key role of DMRT1. Sex Dev. 2007;1:2-11.

29. Kettlewell JR, Raymond CS, Zarkower D. Temperature-dependent expression of turtle Dmrt1 prior to sexual differentiation. Genesis. 2000;26:174-8.

30. Raymond CS, Parker ED, Kettlewell JR, Brown LG, Page DC, Kusz K, et al. A region of human chromosome $9 p$ required for testis development contains two genes related to known sexual regulators. Hum Mol Genet. 1999;8:989-96.

31. Teranishi M, Shimada Y, Hori T, Nakabayashi O, Kikuchi T, Macleod T, et al. Transcripts of the MHM region on the chicken $Z$ chromosome accumulate 
as non-coding RNA in the nucleus of female cells adjacent to the DMRT1 locus. Chromosome Res. 2001;9:147-65.

32. Volff JN, Nanda I, Schmid M, Schartl M. Governing sex determination in fish: regulatory putsches and ephemeral dictators. Sex Dev. 2007;1:85-99.

33. Jeong HB, Park JG, Park YJ, Takemura A, Hur SP, Lee YD, et al. Isolation and characterization of DMRT1 and its putative regulatory region in the protogynous wrasse, Halichoeres tenuispinis. Gene. 2009;438:8-16.

34. Healy C, Uwanogho D, Sharpe PT. Regulation and role of Sox9 in cartilage formation. Dev Dyn. 1999;215:69-78.

35. Jakubiczka S, Schroder C, Ullmann R, Volleth M, Ledig S, Gilberg E, et al. Translocation and deletion around SOX9 in a patient with acampomelic campomelic dysplasia and sex reversal. Sex Dev. 2010;4:143-9.

36. Sekido R, Lovell-Badge R. Sex determination involves synergistic action of SRY and SF1 on a specific Sox9 enhancer. Nature. 2008:453:930-4.

37. Barrionuevo F, Bagheri-Fam S, Klattig J, Kist R, Taketo MM, Englert C, et al. Homozygous inactivation of Sox9 causes complete XY sex reversal in mice. Biol Reprod. 2006;74:195-201.

38. Georg I, Bagheri-Fam S, Knower KC, Wieacker P, Scherer G, Harley VR Mutations of the SRY-responsive enhancer of SOX9 are uncommon in XY gonadal dysgenesis. Sex Dev. 2010;4:321-5.

39. Denny P, Swift S, Brand N, Dabhade N, Barton P, Ashworth A. A conserved family of genes related to the testis determining gene. SRY Nucleic Acids Res. 1992;20:2887.

40. Coriat AM, Muller U, Harry UL, Uwanogho D, Sharpe PT. PCR amplification of SRY-related gene sequences reveals evolutionary conservation of the SRYbox motif. Genome Res. 1993;2:218-22.

41. Zhou R, Liu L, Guo Y, Yu H, Cheng H, Huang X, et al. Similar gene structure of two Sox9a genes and their expression patterns during gonadal differentiation in a teleost fish, rice field eel (Monopterus albus). Mol Reprod Dev. 2003;66:211-7.

42. Chiang EF, Pai Cl, Wyatt M, Yan YL, Postlethwait J, Chung B. Two sox9 genes on duplicated zebrafish chromosomes: expression of similar transcription activators in distinct sites. Dev Biol. 2001;231:149-63.

43. Kluver N, Kondo M, Herpin A, Mitani H, Schartl M. Divergent expression patterns of Sox9 duplicates in teleosts indicate a lineage specific subfunctionalization. Dev Genes Evol. 2005;215:297-305.

44. Shibatta OA, Orsi ML, Bennemann ST, Silva-Souza AT. Diversidade e distribuição de peixes na bacia do rio Tibaji. In: Medri ME, Bianchini E, Shibatta OA, Pimenta JA, editors. A Bacia do rio Tibaji. Londrina: UEL; 2002. p. 595.

45. Orsi ML, Shibatta OA, Silva Souza AT. Caracterização biológica de populaçōes de peixes do Rio Tibaji, localidade de Sertanópolis. In: Medri ME, Bianchine E, Shibatta OA, Pimenta JA, editors. A bacia do Rio Tibaji. Londrina: UEL; 2002. p. 595.

46. Garutti V, Britski HA. Descrição de uma espécie nova de astyanax (Teleostei: Characidae) da bacia do alto rio Paraná e considerações sobre as demais espécies do gênero na bacia. Comun Museu Ciências Tecnol PUCRS 2000;13:65-88.

47. Costa FG, Adolfi MC, Gomes CC, Jesus LWO, Batlouni SR, Borella MI. Testes of Astyanax altiparanae: The Sertoli cell functions in a semicystic spermatogenesis. Micron. 2014;61:20-7.

48. Nomura H. Fecundidade, maturação sexual e índice gônado-somático de lambaris do gênero Astyanax Baird e Girard, 1854 (Osteichthyes, Characidae), relacionados com fatores ambientais. Rev Bras Biol. 1975;35:775-98.

49. Boxshade. http://www.ch.embnet.org/software/BOX_form.html.

50. National Center for Biotechnology Information. http://www.ncbi.nlm.nih.gov.

51. McCurley AT, Callard GV. Characterization of housekeeping genes in zebrafish: male-female differences and effects of tissue type, developmental stage and chemical treatment. BMC Mol Biol. 2008:9:102.

52. Marin I, Baker BS. The evolutionary dynamics of sex determination. Science. 1998:281:1990-4

53. Fernandes CA, Martins-Santos IC. Cytogenetic studies in two populations of Astyanax altiparanae (Pisces, Characiformes). Hereditas. 2004;141:328-32.

54. Chen S, Zhang G, Shao C, Huang Q, Liu G, Zhang P, et al. Whole-genome sequence of a flatfish provides insights into ZW sex chromosome evolution and adaptation to a benthic lifestyle. Nat Genet. 2014;46:253-60.

55. Wilhelm D, Palmer S, Koopman P. Sex determination and gonadal development in mammals. Physiol Rev. 2007:87:1-28.

56. Laudet V, Stehelin D, Clevers H. Ancestry and diversity of the HMG box superfamily. Nucleic Acids Res. 1993;21:2493-501.

57. Nakamoto M, Suzuki A, Matsuda M, Nagahama Y, Shibata N. Testicular type Sox9 is not involved in sex determination but might be in the development of testicular structures in the medaka, Oryzias latipes. Biochem Biophys Res Commun. 2005;333:729-36.

58. Sudbeck P, Schmitz ML, Baeuerle PA, Scherer G. Sex reversal by loss of the C-terminal transactivation domain of human SOX9. Nat Genet. 1996;13:230-2

59. Postlethwait J, Amores A, Cresko W, Singer A, Yan YL. Subfunction partitioning, the teleost radiation and the annotation of the human genome. Trends Genet. 2004;20:481-90.

60. Dehal P, Boore JL. Two rounds of whole genome duplication in the ancestral vertebrate. PLoS Biol. 2005;3:e314.

61. Cresko WA, Yan YL, Baltrus DA, Amores A, Singer A, Rodriguez-Mari A, et al. Genome duplication, subfunction partitioning, and lineage divergence: Sox9 in stickleback and zebrafish. Dev Dyn. 2003;228:480-9.

62. Nelson JS. Fishes of the World. 4th ed. New York: John Wiley and Sons; 2006.

63. Patiño R, Davis KB, Schoore JE, Uguz C, Strüssman CA, Parker NC, et al. Sex differentiation of channel catfish gonads: Normal development and effects of temperature. J Exp Zool. 1996;276:209-18.

64. Strüssmann CA, Takashima F, Toda K. Sex differentiation and hormonal feminization in pejerrey Odontesthes bonariensis. Aquaculture. 1996;139:31-45.

65. Grandi G, Colombo G. Development and early differentiation of gonad in the european Eel (anguilla anguilla [L.], anguilliformes, teleostei): a cytological and ultrastructural study. J Morphol. 1997;231:195-216.

66. Lin F, Dabrowski K, Timmermans LPM. Early gonadal development and sexual differentiation in muskellunge (Esox masquinongy). Can J Zool. 1997;75:1262-9.

67. Nakamura M, Kobayashi T, Chang X-T, Nagahama Y. Gonadal sex differentiation in teleost fish. J Exp Zool. 1998;281:362-72.

68. Devlin R, Nagahama Y. Sex determination and sex differentiation in fish: an overview of genetic, physiological, and environmental influences. Aquaculture. 2002;208:191-364.

69. Weidinger G, Wolke U, Koprunner M, Klinger M, Raz E. Identification of tissues and patterning events required for distinct steps in early migration of zebrafish primordial germ cells. Development. 1999;126:5295-307.

70. Raz E. Primordial germ-cell development: the zebrafish perspective. Nat Rev Genet. 2003;4:690-700

71. Gilbert SF. Developmental Biology. 8th ed. Sinauer: Sunderland; 2006

72. Koopman P, Loffler KA. Sex determination: the fishy tale of Dmrt1. Curr Biol. 2003;13:R177-9.

73. Kurokawa H, Saito D, Nakamura S, Katoh-Fukui Y, Ohta K, Baba T, et al. Germ cells are essential for sexual dimorphism in the medaka gonad. Proc Natl Acad Sci U S A. 2007;104:16958-63.

74. Jorgensen A, Morthorst JE, Andersen O, Rasmussen LJ, Bjerregaard P. Expression profiles for six zebrafish genes during gonadal sex differentiation. Reprod Biol Endocrinol. 2008;6:25

75. Schartl M. Sex chromosome evolution in non-mammalian vertebrates. Curr Opin Genet Dev. 2004;14:634-41.

76. Morais Da Silva S, Hacker A, Harley V, Goodfellow P, Swain A, Lovell Badge R. Sox9 expression during gonadal development implies a conserved role for the gene in testis differentiation in mammals and birds. Nat Genet. 1996;14:62-8.

77. Moreno-Mendoza N, Harley VR, Merchant-Larios H. Differential expression of SOX9 in gonads of the sea turtle Lepidochelys olivacea at male- or female-promoting temperatures. J Exp Zool. 1999;284:705-10.

78. Yokoi H, Kobayashi T, Tanaka M, Nagahama Y, Wakamatsu Y, Takeda H, et al. Sox9 in a teleost fish, medaka (Oryzias latipes): evidence for diversified function of Sox9 in gonad differentiation. Mol Reprod Dev. 2002;63:5-16.

79. Li MH, Yang HH, Li MR, Sun YL, Jiang XL, Xie QP, et al. Antagonistic roles of Dmrt1 and Foxl2 in sex differentiation via estrogen production in tilapia as demonstrated by TALENs. Endocrinology. 2013;154:4814-25.

80. Masuyama H, Yamada M, Kamei Y, Fujiwara-Ishikawa T, Todo T, Nagahama $Y$, et al. Dmrt1 mutation causes a male-to-female sex reversal after the sex determination by Dmy in the medaka. Chromosome Res. 2012;20:163-76.

81. Nakamura S, Watakabe I, Nishimura T, Toyoda A, Taniguchi Y, Tanaka M. Analysis of medaka sox 9 orthologue reveals a conserved role in germ cell maintenance. PLoS One. 2012;7:e29982.

\section{doi:10.1186/1477-7827-13-2}

Cite this article as: Adolfi et al:: Molecular cloning and expression analysis of dmrt1 and sox9 during gonad development and male reproductive cycle in the lambari fish, Astyanax altiparanae. Reproductive Biology and Endocrinology 2015 13:2. 